\title{
Penerapan Model Pembelajaran Kooperatif Team Game Tournament (TGT) pada Pokok Bahasan Pengukuran Luas Bangun Datar untuk Meningkatkan Aktivitas dan Hasil Belajar Siswa Kelas V SD Katolik "ST. Petrus" Banyuwangi \\ (Application of Cooperative Learning Model Team Games Tournament (TGT) on the Large Measurement Plane to Increase Activities and Learning Outcomes Student Class V SD Catholics "ST. Petrus "Banyuwangi)
}

\author{
Agata Elok Febriliana, Titik Sugiarti, Khutobah. \\ Jurusan Ilmu Pendidikan, Fakultas Keguruan dan Ilmu Pendidikan, Universitas Jember (UNEJ) \\ Jln. Kalimantan 37, Jember 68121 \\ E-mail : titiksugiarti.fkip@unej.ac.id
}

\begin{abstract}
Abstrak
Matematika sangat membantu dan dibutuhkan pada bidang studi atau ilmu-ilmu yag lain. Oleh karena itu matematika merupakan mata pelajaran yang mutlak untuk dipelajari dan dikuasai. Semakin tinggi pemahaman dan penguasaan materi serta prestasi belajar maka semakin tinggi pula tingkat keberhasilan pembelajaran. Pada kenyataan di lapangan, siswa sering mengalami kesulitan dalam belajar matematika sehingga hasil belajar siswa dalam mata pelajaran matematika pun menjadi rendah. Oleh karena itu dilakukan penelitian tindakan kelas dengan siswa kelas $V$ sebagai subjek penelitiannya. Penelitian ini dilaksanakan dalam dua siklus. Pengumpulan data yang digunakan dalam penelitian ini menggunakan metode tes, observasi, wawancara, dan dokumentasi. Tujuan penelitian ini adalah untuk meningkatkan aktivitas dan hasil belajar siswa kelas $\mathrm{V}$ dalam pembelajaran matematika pokok bahasan pengukuran kecepatan melalui penerapan metode pembelajaran kooperatif team game tournament. Pada siklus I, Skor aktivitas siswa secara klasikal sebesar 75,59 yang tergolong aktif dan pada siklus II meningkat menjadi 81,20 yang tergolong sangat aktif. Skor hasil belajar siswa secara klasikal pada siklus I sebesar 72,31 yang tergolong naik dan pada siklus II meningkat menjadi 80,59 yang tergolong sangat baik. Hasil penelitian ini menunjukkan bahwa penerapan metode pembelajaran kooperatif team game tournament dapat meningkatkan aktivitas dan hasil belajar siswa dalam pembelajaran matematika pokok bahasan pengukuran kecepatan pada siswa kelas V di SD ST. Petrus Banyuwangi.
\end{abstract}

Kata Kunci : Aktivitas Belajar Siswa, Hasil Belajar Siswa, Metode kooperatif Abstract

Math is very helpful and it takes on a field of study or other sciences. Therefore, math is a subject that is absolutely to be learned and mastered. The higher the understanding and mastery of the material and learning achievement, the higher the success rate of learning. In the circumstances, students often have difficulty in learning mathematics so that student learning outcomes in mathematics becomes low. Therefore do action research with fifth grade students as research subjects. This study was conducted in two cycles. The collection of data used in this study using the test method, observation, interviews, and documentation. The purpose of this research is to improve the activity and class $V$ student learning outcomes in mathematics subject velocity measurements through the implementation of cooperative learning team game tournament. In the first cycle, the student activity in classical scores at 75.59 belonging to the active and the second cycle increased to 81.20 were classified as very active. Scores of student learning outcomes in the classical style in the first cycle of 72.31 belonging rise and the second cycle increased to 80.59 which is exceptionally good. The results of this study indicate that the application of cooperative learning team tournament games can increase the activity and student learning outcomes in mathematics subject at the speed measuring fifth grade students at SD ST. Petrus Banyuwangi..

Keywords : Student Activities, Student Outcomes, kooperatif method

\section{Pendahuluan}

Matematika merupakan ilmu pengetahuan yang mempelajari struktur yang abstrak dan pola hubungan yang ada didalamnya [3]. Dienes mengatakan bahwa matematika adalah ilmu seni kreatif [1]. Oleh karena itu, matematika harus dipelajari dan diajarkan sebagai ilmu seni. Menurut Sumarmo pelajaran matematika berkaitan dengan penalaran yang bersifat deduktif, materi matematika bersifat hierarkis dan terstruktur [4]. Selain itu matematika sangat membantu 
dan dibutuhkan pada bidang studi atau ilmu-ilmu yang lain. Oleh karena itu matematika merupakan mata pelajaran yang mutlak untuk dipelajari dan dikuasai. Semakin tinggi pemahaman dan penguasaan materi serta prestasi belajar maka semakin tinggi pula tingkat keberhasilan pembelajaran. Pada kenyataan di lapangan, siswa sering mengalami kesulitan dalam belajar matematika sehingga hasil belajar siswa dalam mata pelajaran matematika pun menjadi rendah.

Berdasarkan hasil observasi yang dilakukan di SD Katolik "ST. Petrus" Jajag Banyuwangi sebagian besar metode pembelajaran masih terpusat pada guru. Hal ini mengakibatkan siswa hanya duduk tenang di bangku, mendengarkan serta menyerap dan menyimpan informasi, kemudian mencatat dan mengerjakan soal latihan yang diberikan oleh guru. Aktivitas pembelajaran yang seperti ini kurang sesuai dengan prinsip pembelajaran matematika yang menuntut siswa agar turut serta dalam memahami, menganalisis, praktek dan penerapannya terhadap lingkungan. Pada akhirnya pembelajaran di sekolah ini masih cenderung bersifat teoritik dan tidak terkait dengan lingkungan dan kehidupan sehari-hari dimana anak berada, sehingga materi yang disampaikan sulit untuk diterima oleh siswa.

Berdasarkan hasil observasi dan wawancara dengan guru kelas V SD Katolik "ST. Petrus" Jajag Banyuwangi pada bulan Agustus 2015, pembelajaran matematika dipandang sulit oleh kebanyakan siswa sehingga pelajaran matematika kurang diminati dan cenderung ditakuti. Pembelajaran matematika juga masih menekankan konsep-konsep yang ada dalam buku. Selama ini ceramah dan diskusi masih menjadi pilihan utama guru dalam mengajar. Proses pembelajaran seperti ini kurang menarik perhatian siswa, sehingga menyebabkan aktivitas dan hasil belajar siswa rendah. Rendahnya aktivitas belajar Matematika siswa kelas V dalam proses pembelajaran dapat diketahui melalui banyaknya siswa yang tidak memperhatikan penjelasan guru, mengobrol, mengganggu teman, dan lain-lain. Aktivitas belajar yang rendah juga menjadi penyebab kurangnya pemahaman dan penguasaan materi, yang berimbas pada rendahnya hasil belajar. Hasil belajar siswa secara individual rata-rata nilai siswa 65,26 , sementara KKM yang ditetapkan adalah sebeasar 75 . Ketuntasan klasikal siswa baru mencapai $62,1 \%$ sementara target yang ditetapkan adalah sebesar $80 \%$. Secara keseluruhan hasil belajar masih belum menunjukkan keberhasilan yang memuaskan. Kendala dalam pembelajaran matematika muncul dari berbagai faktor antara lain sebagian besar siswa menganggap bahwa pelajaran matematika adalah mata pelajaran yang paling menakutkan dan dihindari karena dianggap sulit dibanding mata pelajaran lain yang ada di Sekolah Dasar. Selain itu guru cenderung masih menggunakan metode ceramah saja dimana guru menjelaskan dan tugas siswa hanya mendengarkan, tanpa disadari dengan metode ceramah yang dilakukan guru menjadikan siswa cepat bosan dan tidak tertarik mempelajari matematika. Guru juga belum dapat mengoptimalkan sumber belajar di lingkungan sekitarnya. Dalam memberikan pelajaran matematika, guru hanya bersumber pada buku pegangan. Buku pegangan dijadikan pedoman satu-satunya sebagai sumber belajar siswa. Melihat kondisi seperti itu sudah menjadi tugas seorang guru agar mau dan mampu mengadakan perubahan pada proses pembelajaran agar anak secara menyeluruh aktif dan mampu menyerap dan memahami materi pelajaran. Dalam proses belajar mengajar sebaiknya siswa juga diberi kesempatan untuk dapat bertukar pikiran dengan teman karena interaksi dengan teman sebaya dalam pembelajaran dapat membantu siswa dalam memahami materi pelajaran.

Slavin Pembelajaran Kooperatif adalah suatu pembelajaran dimana siswa belajar dan bekerja dalam kelompok kelompok kecil secara kolaboratif yang anggotanya 5 orang dengan struktur kelompok heterogen [2]. Pembelajaran kooperatif merupakan suatu cara pendekatan atau serangkaian strategi yang khusus dirancang untuk memberi dorongan kepada siswa agar bekerja sama selama proses pembelajaran. Pembelajaran kooperatif adalah pembelajaran yang berfokus pada penggunaan kelompok kecil siswa untuk bekerja sama dalam memaksimalkan kondisi belajar untuk mencapai tujuan belajar

Pembelajaran Cooperative learning tidak sama dengan sekedar belajar dalam kelompok. Ada lima unsur dasar pembelajaran Cooperative learning yang membedakannya dengan pembagian kelompok yang dilakukan asal-asalan. Pelaksanaan pembelajaran kooperatif dengan benar akan menunjukkan pendidik mengelola kelas lebih efektif. pembelajaran kooperatif ada lima unsur yaitu: saling ketergantungan positif, tanggung jawab perseorangan, tatap muka, komunikasi antar anggota, dan evaluasi proses kelompok. Pembelajaran kooperatif (Cooperative learning) adalah pembelajaran yang menekankan pada saling ketergantungan positif antar individu siswa, adanya tanggung jawab perseorangan, tatap muka, komunikasi intensif antar siswa, dan evaluasi proses kelompok). Cooperative learning merujuk pada berbagai macam pembelajaran di mana para siswa bekerja sama dalam kelompok-kelompok kecil yang terdiri dari berbagai tingkat prestasi, jenis kelamin, dan latar belakang etnik yang berbeda untuk saling membantu satu sama lain dalam mempelajari materi pelajaran [4]. Dalam kelas kooperatif, para siswa diharapkan dapat saling membantu, saling mendiskusikan, dan berargumentasi untuk mengasah pengetahuan yang mereka kuasai saat itu dan menutup kesenjangan dalam pemahaman masing-masing. Cooperative learning lebih dari sekedar belajar kelompok karena dalam pembelajaran ini harus ada struktur dorongan dan tugas yang bersifat kooperatif sehingga memungkinkan terjadi interaksi secara terbuka dan hubungan-hubungan yang bersifat interdependensi efektif antara anggota kelompok.

Berdasarkan uraian di atas perlu dilakukan penelitian tindakan kelas untuk mengetahui lebih mendalam penerapan metode belajar dalam meningkatkan hasil belajar dan aktivitas belajar siswa dengan judul Penerapan Model Pembelajaran Kooperatif Team Game Tournament (TGT) pada Pokok Bahasan Pengukuran Kecepatan untuk Meningkatkan Aktivitas dan Hasil Belajar Siswa Kelas V SD Katolik "ST. Petrus" Banyuwangi. 


\section{Metode Penelitian}

Penelitian ini dilaksanakan di SD Katolik "ST. Petrus" Banyuwangi semester ganjil tahun pelajaran 2016/2017 yang beralamatkan di Jl. Yos Sudarso No. 14 Gambiran. Pelaksanaan penelitian dilakukan pada kelas V semester genap tahun pelajaran 2015/2016 pada pembelajaran pengukuran kecepatan. Penelitian dimulai pada bulan agustus 2015 dengan melakukan kegiatan observasi dan wawancara kepada guru kelas V SD Katolik "ST. Petrus" Banyuwangi. Observasi ini dilaksanakan dengan tujuan untuk mengetahui proses pembelajaran di kelas $\mathrm{V}$, baik yang dilakukan oleh guru maupun siswa, setelah dilakukan observasi dan wawancara, peneliti dan guru kelas V berdiskusi untuk melaksanakan persiapan penelitian. Prosedur pelaksanaan PTK yang digunakan mengacu pada model skema spiral dari Hopkins yang terdiri dari empat tahapan yaitu perencanaan, tindakan, observasi, dan refleksi. Senada dengan pendapat tersebut, maka model yang digunakan dalam penelitian ini adalah model Hopskin. Hopskin menggambarkan adanya empat langkah. Penelitian dimulai dari perencanaan (planning), pelaksanaan tindakan (action), observasi (observation), dan refleksi (reflection) yang dapat diulang secara siklus. Refleksi merupakan pemaknaan hasil tindakan yang dilakukan dalam rangka memecahkan masalah. Keempat siklus tersebut merupakan siklus pertama yang diawali dengan perencanaan, pelaksanaan, pengamatan, dan refleksi yang diikuti siklus berikutnya. Pengumpulan data dilakukan dengan observasi, wawancara, dokumentasi dan tes.

Data yang dianalisis dalam penelitian ini adalah sebagai berikut.

1) Untuk menghitung skor pencapaian aktivitas belajar siswa selama proses pembelajaran, menggunakan rumus :

Keterangan :

$$
\mathrm{Pa}=\frac{N}{A} \times 100
$$

$\mathrm{Pa}=$ skor pencapaian aktivitas belajar siswa

$\mathrm{A}=$ jumlah skor komponen penilaian aktivitas belajar yang dicapai siswa

$\mathrm{N}=$ jumlah skor maksimal dari komponen penilaian aktivitas belajar siswa

Kriteria aktivitas belajar siswa dapat dilihat pada tabel 1 .

Tabel 1. Kriteria Aktivitas Belajar Siswa

\begin{tabular}{|c|c|c|}
\hline No & Kriteria Aktivitas Belajar & Rentangan Skor \\
\hline 1. & Sangat Aktif & $81-100$ \\
\hline 2. & Aktif & $61-80$ \\
\hline 3. & Cukup Aktif & $41-60$ \\
\hline 4. & Kurang Aktif & $21-40$ \\
\hline 5. & Sangat Kurang Aktif & $0-20$ \\
\hline
\end{tabular}

2) Untuk menghitung skor pencapaianhasil belajar siswa rumus sebagai berikut :

$$
\mathrm{Pa}=\frac{n}{N} \quad \mathrm{X} 100
$$

keterangan :

$\mathrm{P}=$ skor pencapaian hasil belajar siswa

$\mathrm{n}=$ jumlah skor hasil belajar yang diperoleh siswa

$\mathrm{N}=$ jumlah skor maksimal hasil belajar siswa

Kriteria hasil belajar siswa dapat dilihat pada tabel 2 .

Tabel 2. Kriteria Hasil Belajar Siswa

\begin{tabular}{|c|c|c|}
\hline No. & Kriteria Hasil Belajar & Rentangan Skor \\
\hline 1. & Sangat Baik & $80-100$ \\
\hline 2. & Baik & $70-79$ \\
\hline 3. & Cukup Baik & $60-69$ \\
\hline 4. & Kurang Baik & $40-59$ \\
\hline 5. & Sangat Kurang Baik & $0-39$ \\
\hline
\end{tabular}

\section{Hasil dan Pembahasan}

Penelitian ini merupakan penelitian tindakan kelas (PTK) yang bertujuan untuk meningkatkan aktivitas dan hasil belajar siswa melalui penerapan model pembelajaran kooperatif team game tournament. Penelitian ini dilaksanakan sebanyak 2 siklus.

Siklus I dilaksanakan pada hari Senin tanggal 15 Agustus 2016, sedangkan siklus II pada hari selasa tanggal 23 Agustus 2016. Pelaksanaan siklus I dan siklus II diterapkan melalui 4 tahap yaitu perencanaan, pelaksanaan, observasi dan refleksi pada tahap observasi, peneliti dibantu oleh oleh 4 orang observer pada siklus I dan 4 orang observer pada siklus II. Observer bertugas mengamati aktivitas belajar siswa selama pembelajaran berlangsung. Dalam pelaksanaan siklus I maupun siklus II terjadi peningkatan aktivitas dan hasil belajar siswa dengan menerapkan pembelajaran kooperatif pada mata pelajaran matematika.

1) Aktivitas Belajar Siswa

Berdasarkan observasi pada siklus I dan siklus II terjadi peningkatan aktivitas belajar siswa. Peningkatan terjadi pada seluruh aspek yang diamati yakni aktivitas mencatat,mendengarkan, membaca, bertanya, mengeluarkan pendapat, menulis, bermai peran, serta menaruh minat. Hasil observasi menunjukkan bahwa pada siklus I skor aktivitas belajar siswa secara klasikal sebesar 64,29 yang tergolong aktif, sedangkan pada siklus II Skor aktivitas belajar siswa sebesar 81,20 dan tergolong kategori sangat aktif. Peningkatan aktivitas belajar siswa dari siklus I ke siklus II dapat dilihat pada tabel 3 .

\begin{tabular}{|c|c|c|c|c|c|}
\hline \multirow[t]{2}{*}{ No } & \multirow{2}{*}{$\begin{array}{c}\text { Kategori } \\
\text { Aktivitas Belajar }\end{array}$} & \multicolumn{2}{|c|}{ Siklus I } & \multicolumn{2}{|c|}{ Siklus II } \\
\hline & & Frek. & (\%) & Frek. & $(\%)$ \\
\hline 1. & Sangat Aktif & 6 & 17,56 & 14 & 41,26 \\
\hline 2. & Aktif & 24 & 70,59 & 19 & 55,6 \\
\hline 3. & Cukup Aktif & 4 & 11,76 & 1 & 2,94 \\
\hline 4. & Kurang Aktif & 0 & 0 & 0 & 0 \\
\hline 5. & $\begin{array}{c}\text { Sangat Kurang } \\
\text { Aktif }\end{array}$ & 0 & 0 & 0 & 0 \\
\hline & Jumlah & 34 & 100 & 34 & 100 \\
\hline
\end{tabular}

Tabel 3. Perbandingan antara aktivitas belajar siswa 
Dari tabel tersebut diketahui adanya peningkatan aktivitas belajar dari prasiklus ke siklus I. Hal itu ditunjukkan dari peningkatan aktivitas belajar siswa setiap kategori. Kategori sangat aktif sebesr 17,56\%, kategori aktif sebesar 70,59\%, kategori cukup aktif sebesar $11,76 \%$, kategori kurang aktif sebesar $0 \%$, dan sangatkurag aktif sebesar $0,00 \%$, sedangkan pada siklus II aktivitas belajar siswa yang tergolong dalam kategori sangat aktif sebesar 41,26\%, kategori aktif sebesar 55,6\%, kategori cukup aktif sebesar 2,94\%, kategori kurang aktif sebesar $0 \%$, dan kategori sangat kurang aktif sebesar $0,00 \%$.

\section{2) Hasil Belajar Siswa}

Berdasarkan observasi pada siklus I dan siklus II menunjukkan adanya peningkatan hasil belajar siswa. Pada siklus I, skor hasil belajar siswa secara klasikal sebesar 72,31 yang tergolong baik meningkat menjadi 80,16 yang tergolong sangat baik. Peningkatan hasil belajar siswa dapat dilihat pada tabel 4 . siswa, mereka tidak merasa takut lagi dalam mengikuti pembelajaran,

c) Kegiatan pembelajaran di dalam kelas beberapa siswa terlihat masih malu-malu dan membaca hasil diskusinya kurang terdengar oleh siswa lain, akan tetapi pada pertemuan selanjutnya sebagian besar siswa sudah tidak malu-malu dan membacanya sudah agak keras karena telah diberikan motivasi dan akan di beri penghargaan bagi siswa yang mengikuti pembelajaran dengan baik,

Skor aktivitas belajar siswa kelas V SD katolik ST. Petrus Banyuwangi dalam pembelajaran sebelum tindakan sebesar 39,35 tergolong dalam kategori kurang aktif. Setelah pelaksanaan pembelajaran tema 8 melalui penerapan pembelajaran kooperatif tipe TGTberbantuan media animasi, skor aktivitas belajar siswa pada siklus I sebesar 73,22 tergolong dalam kategori aktif dan pada siklus II sebesar 75,97 tergolong dalam kategori aktif.
Tabel 4. Perbandingan antara hasil belajar siswa dari siklus I

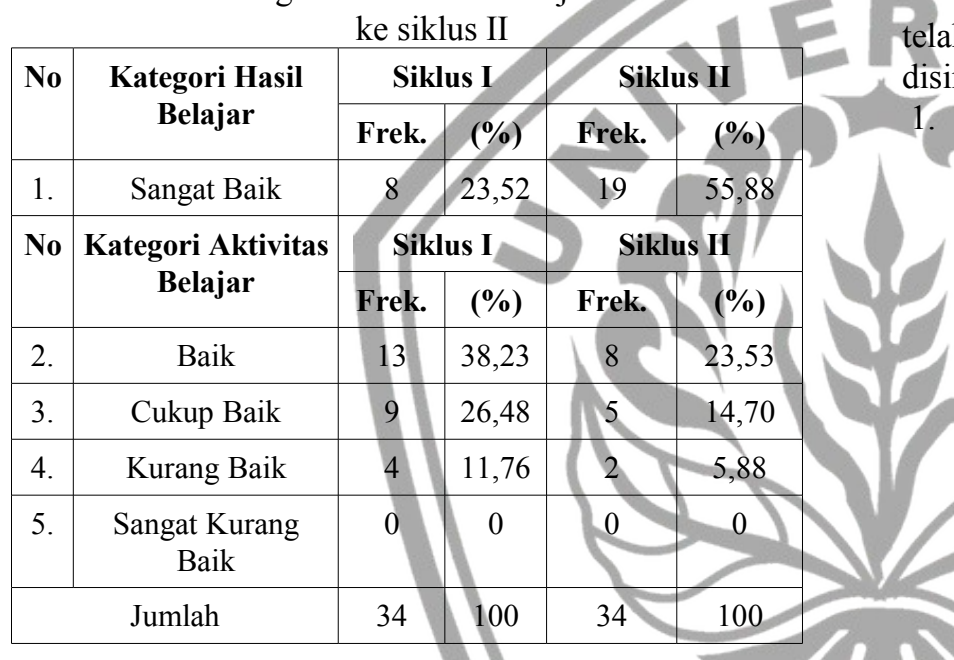

Dari tabel tersebut diketahui adanya peningkatan hasil belajar siswa dari siklus I ke siklus II. Hal itu ditunjukkan dari peningkatan hasil belajar siswa setiap kategori. Pembelajaran kooperati8f TGT dapat meningkatkan aktivitas dan hasil belajar siswa, khususnya dalam penelitian ini yaitu pembelajaran matematika di kelas $\mathrm{V}$ dengan pokok bahasan pengukuran kecepatan.

3) Temuan Penelitian

Berdasarkan pelaksanaan penelitian yang telah dilaksanakan dalam dua siklus, maka ditemukan beberapa temuan sebagai berikut.

a) Pembelajaran siklus I siswa mulai ramai ketika pembagian kelompok. Hal ini disebabkan karena siswa harus pindah tempat duduk sesuai dengan kelompok yang telah ditentukan dan belum terbiasa dengan teman yang dipilih dalam satu kelompoknya. Pada pertemuan siklus II selanjutnya dapat diatasi karena pembentukan kelompok sudah ditetapkan,

b) Kesulitan yang dialami siswa pada saat pembelajaran, terutama pada saat siklus I. Siswa belum terbiasa belajar dengan model pembelajaran kooperatif tipe TGT, sehingga diawal pembelajaran mereka sempat merasa takut. Namun, setelah guru (peneliti) memberikan bimbingan kepada

\section{Kesimpulan dan Saran}

Berdasarkan hasil penelitian dan pembahasan yang telah diuraikan pada bab sebelumnya, maka dapat disimpulkan sebagai berikut.

1. Penelitian ini dilakukan berdasarkan tahapan model pembelajaran kooperatif tipe TGT yaitu penempatan siswa ke dalam tim, belajar tim, penempatan siswa ke dalam meja tournament, melakukan tournament, dan rekognisi tim. Penelitian yang dilakukan selama dua siklus ini mampu membuat siswa antusias dalam mengikuti pembelajaran, utamanya dalam tournament namun terdapat beberapa kendala yaitu kurangnya keaktifan siswa pada aspek berdiskusi dengan tim. Hal tersebut karena siswa belum memperhatikan aturan game dan kurang paham terhadap materi yang di ajarkan . Oleh karena itu pembelajaran menjadi kurang efektif dan perlu dilakukan perbaikan pada siklus II dengan mengajak siswa untuk berinteraksi dengan teman diskusi. Hasilnya pembelajaran tampak lebih terorganisir.

2. Penerapan model pembelajaran kooperatif Team Game Tournament (TGT) pada pokok bahasan luas bangun datar dapat meningkatkan aktivitas belajar siswa kelas V SD Katolik "ST. Petrus" Banyuwangi. Hal ini dapat dilihat skor rata-rata aktivitas belajar siswa pada pra siklus sebesar 42,06 (kurang aktif), siklus I sebesar 75,59 (aktif), dan siklus II sebesar 80,59 (sangat aktif).

3. Penerapan model pembelajaran kooperatif Team Game Tournament (TGT) pada pokok bahasan luas bangun datar dapat meningkatkan hasil belajar siswa kelas V SD Katolik "ST. Petrus" Banyuwangi. Hal ini dapat dilihat skor rata-rata hasil belajar siswa pada pra siklus sebesar 63,75 (cukup baik), siklus I sebesar 71,47 (baik), dan siklus II sebesar 80,03 (sangat baik).

Adapun saran yang dapat dikemukakan sehubungan dengan penelitian ini adalah sebagai berikut.

1) Bagi guru

a) penerapan model pembelajaran kooperatif Team Game Tournament (TGT) hendaknya dapat dijadikan alternatif pilihan bagi guru untuk diterapkan dalam pembelajaran 
di kelas agar siswa lebih tertarik dalam kegiatan pembelajaran

b) Guru hendaknya mencoba menerapkan model pembelajaran kooperatif Team Game Tournament (TGT) dalam pembelajaran tema yang lain, sehingga pembelajaran yang diberikan dapat bervariasi dan dapat menumbuhkan minat belajar siswa

2) Bagi kepala sekolah

a) hendaknya memotivasi guru untuk menerapkan pembelajaran kooperatif Team Game Tournament pada mata pelajaran matematika.

b) diadakan sosialisasi kepada guru-guru agar pembelajaran kooperatif Team Game Tournament dapat dijadikan sebagai salah satu alternatif dalam pemilihan metode pembelajaran di kelas dalam rangka meningkatkan serta mengembangkan mutu pendidikan di sekolah tersebut

3) Bagi peneliti lain

a) hasil penelitian ini dapat dijadikan acuan untuk melakukan penelitian sejenis guna menambah wawasan dalam upaya meningkatkan aktivitas dan hasil belajar siswa melalui penerapan pembelajaran kooperatif team game tournament yang disesuaikan dengan materi pembelajaran serta kondisi siswa di kelas

b) penelitian ini hendaknya dapat dijadikan masukan untuk melaksanakan penelitian sejenis.

\section{Daftar Pustaka}

[1] Dienes, dkk. 2012. Penelitian Tindakan Kelas. Jakarta : Bumi Aksara.

[2] Slavin, R. 2005. Cooperative Learning .Bandung; Nusa Media

[3] Subarinah. 2006. Pembelajaran Menciptakan Proses Belajar Mengajar yang Kreatif dan Efektif. Jakarta: Bumi Aksara.

[4] Sumarmo. 2002. Paradigma Baru Pendidikan Kewarganegaraan Panduan kuliah Di Perguruan Tinggi. Jakarta: Bumi Aksara. 